Jap. J. M. Sc. \& Biol., 10, 329-342, 1957

\title{
QUANTITATIVE STUDIES ON ANAPHYLAXIS IN VITRO \\ III. COMPARISON BETWEEN SCHULTZ-DALE'S REACTION AND SEROLOGICAL REACTIONS IN VITRO
}

\author{
KIMISHIge ISHIZAKA ${ }^{1)}$, TERUKo ISHIZAKA ${ }^{2}$, TAKAO SUGAHARA ${ }^{3)}$ \\ AND Setsuo MATSUNAGA4) \\ Department of Serology, National Institute of Health, Tokyo5)
}

(Received: August 24th, 1957)

It is clear that the anaphylactic reaction is caused by the combination between tissue antibody and antigen. In this connection, quantitative relation between the concentration of tissue antibody and the concentration of antigen required to cause an anaphylactic contraction of the intestine was studied in the previous report (Ishizaka et al., 1956). As a result of this, it was proved that the relation is hyperbolic provided that both concentrations were represented in terms of logarithmic scale. In other words, the inhibition of anaphylactic contraction due to antigen excess was never observed though its reason remains unexplained.

The present communication records additional peculiarities observed in the quantitative proportion between antibody and antigen to yield anaphylactic reaction, especially in comparison with precipitation and complement fixation reaction.

\section{MATERIALS AND Methods}

Antigen used was bovine serum albumin of Armour \& Co. Rabbits were immunized with alum-precipitated BSA (bovine serum albumin). The dosage of 0.1 to $10 \mathrm{mg}$ was given intravenously in series of 4 daily doses at 3 days' intervals between series. When animals had received 16 doses of BSA, they were bled one week after the final dose. The antiserum was fractionated following Nichol and Deutsch (1948) and crude $\gamma$-globulin, $\gamma_{2}$-globulin and $\beta+\gamma_{1}$-globulin fractions were obtained. These fractions were labeled with $\mathrm{I}^{131}$. The procedures of iodination as well as the measurement of radioactivity were those described in the previous report (Ishizaka et al., 1956). The mean number of iodine atoms per molecule of protein was calculated. They were $0.38,0.43,0.56$ and 0.48 atoms per globulin molecule in two crude $\gamma$-globulin fractions, $\beta+\gamma_{1}$-globulin fraction and $\gamma_{2}$-globulin fraction, respectively.

Antibody nitrogen contained in these labeled fractions was determined following Heidelberger and Kendall (1935).

Determination of the degree of sensitization was carried out by the same pro-

1)石坂公成・2)石坂照子・3)菅原孝雄・4)松永節雄, 5)国立予防衛生研究所血清部 
cedure as described in the previous report. Namely, guinea pigs were sensitized by the intravenous injection of varying doses of the $I^{131}$ labeled antibody. Twenty-four hours later, they were bled and the intestines were removed. The anaphylactic contraction of the intestinal strips against various concentrations of BSA dropped into the bath was observed and its intensity was determined by the concentration of acetylcholine chloride required to cause an equivalent contraction. As shown in Fig. 1, the specific contractions of intestinal strips of a sensitized guinea pig caused by $0.42 \mu \mathrm{gN} / \mathrm{cc}$ and $0.51 \mu \mathrm{gN} / \mathrm{cc}$ of $\mathrm{BSA}$ in a Dale bath were equivalent to the contractions caused by acetylcholine at the concentrations of $0.65 \times 10^{-8}$ and $1.0 \times 10^{-8} \mathrm{~g} / \mathrm{cc}$, respectively. By the application of this method, the concentration of antigen required to cause an anaphylactic contraction in a certain intensity (which corresponds to the one caused by acetylcholine of $10^{-8} \mathrm{~g} / \mathrm{cc}$ ) was determined in each animal.

The concentration of tissue antibody in the intestine was estimated from its radioactivity. The procedure was the same as reported in the previous report.
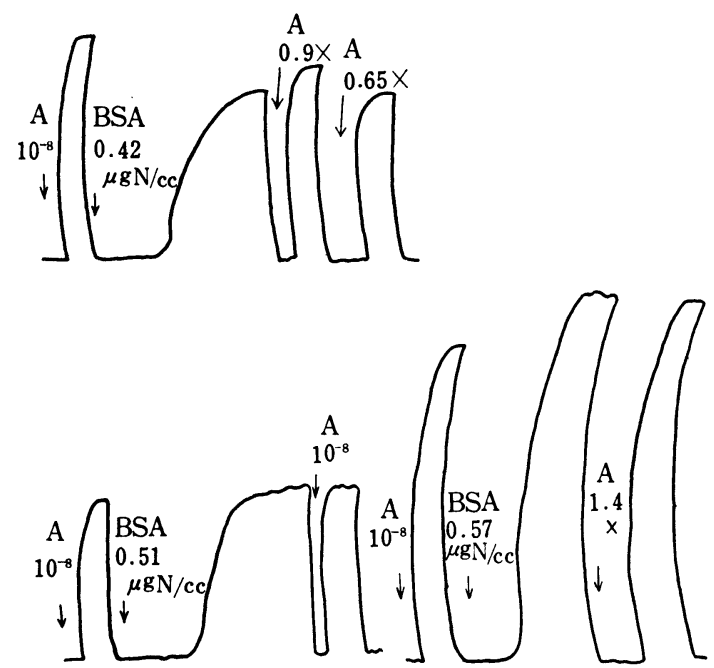

Fig. 1. Quantitative determination of anaphylactic contraction with acetylcholine.

A: acetylcholine chloride BSA: bovine serum albumin

Ring test and complement fixation test were made between the same antigen and antibody to determine the optimal proportion. Technique of the qualitative complement fixation test was that used by the Division of Virus and Rickettsial Disease, Army Medical 'School, U. S. Army Medical Center. In order to increase the sensitivity of the method, veronal buffered saline with the addition of gelatin (Stein et al., 1950) was used as diluent instead of saline. Optimal proportion titrations were performed as follows. Serial dilutions of antigen were prepared in $0.25 \mathrm{cc}$ volume. $0.5 \mathrm{cc}$ of complement containing 2 units and $0.25 \mathrm{cc}$ of diluted antiserum were added to each dilution of antigen. They were incubated for 16 to 18 hours at $4^{\circ}$ to $6^{\circ} \mathrm{C}$. After incubation, $0.5 \mathrm{cc}$ of sensitized red cell suspension was added and the tubes were incubated for 30 minutes at $37^{\circ} \mathrm{C}$ to effect hemolysis. After the optimal proportion was determined, quantitative complement fixation reaction was carried out using the suitable dosis of antigen and antibody in the optimal proportion. The method of quantitative complement fixation test was the one reported by Mayer et al. (1948). 


\section{RESULTS}

1. Relation between the Concentration of Tissue Antibody and the Concentration of Antigen Required to Cause an Anaphylactic Contraction in a Certain Intensity.

Two antisera were fractionated with alcohol, and crude $\gamma$-globulin fractions were obtained. These fractions were labeled with $\mathrm{I}^{131}$ and the quantitative precipitin reaction was carried out. Thereby, the antibody nitrogen contained in the two samples was $1.027 \mathrm{mg}$ and $1.442 \mathrm{mg} / \mathrm{cc}$. Varying amounts of antibody solutions were injected into guinea pigs and 24 hours later the degree of sensitization of each animal was determined by the procedure described above. The intestines were rinsed for 1 hour in Tyrode's solution and their

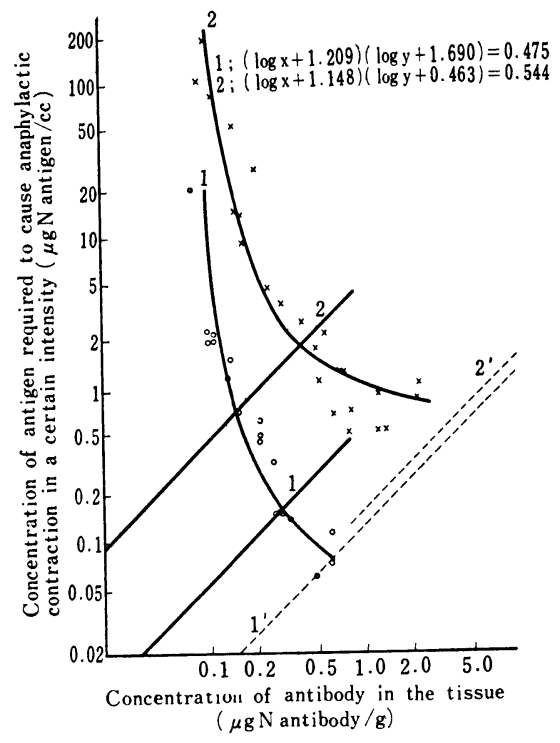

Fig. 2. Proportion of antigen to antibody in anaphylaxis in vitro. - equivalent in precipitation.

radioactivities were determined. The tissue antibody concentration of each animal was estimated from the radioactivity. The results obtained were shown in Table 1. The relation between the concentration of tissue antibody and the concentration of antigen required to cause the stipulated contraction was illustrated in Fig. 2. In this figure, both concentrations are presented in logarithmic scale.

As reported in the previous report, the relation between the concentration of tissue antibody and the concentration of antigen required to cause an anaphylactic reaction in a certain intensity was hyperbolic, and this seems 
Table 1. Relationship between the tissue antibody and antigen required to cause an anaphylactic contraction comparable to the one caused by acetylcholine in the concentration of $10^{-8} \mathrm{~g} / \mathrm{cc}$

\begin{tabular}{|c|c|c|c|c|c|}
\hline No & $\begin{array}{c}\text { Body } \\
\text { Weight }\end{array}$ & $\begin{array}{l}\text { Antibody } \\
\text { in:ected }\end{array}$ & $\begin{array}{l}\text { Circulating } \\
\text { antibody }\end{array}$ & $\begin{array}{l}\text { Tissue } \\
\text { antibody }\end{array}$ & $\begin{array}{l}\text { Antigen concen- } \\
\text { tration required* }\end{array}$ \\
\hline \multicolumn{6}{|c|}{ 1) Crude $\gamma$-globulin fraction(1) } \\
\hline & $\mathrm{g}$ & $\mu \mathrm{gN} / 100 \mathrm{~g}$ & $\mu \mathrm{gN} / \mathrm{cc}$ & $\mu \mathrm{gN} / \mathrm{g}$ & $\mu \mathrm{gN} / \mathrm{cc}$ \\
\hline 1 & 325 & 78.8 & 4.6 & 0.216 & 0.445 \\
\hline 2 & 310 & 165 & 8.62 & 0.32 & 0.16 \\
\hline 3 & 320 & 32.3 & 1.89 & 0.095 & 2.36 \\
\hline 4 & 340 & 226 & 10.9 & 0.489 & 0.0629 \\
\hline 5 & 290 & 53.1 & 2.95 & 0.109 & 2.36 \\
\hline 6 & 265 & 193 & 8.4 & 0.619 & 0.076 \\
\hline 7 & 280 & 91.5 & 4.6 & 0.157 & 0.734 \\
\hline 8 & 285 & 69.5 & 3.9 & 0.143 & 1.57 \\
\hline 9 & 290 & 53.1 & 2.95 & 0.109 & 2.10 \\
\hline 10 & 305 & 101 & 4.36 & 0.213 & 0.63 \\
\hline 11 & 295 & 132 & 5.69 & 0.210 & 0.524 \\
\hline 12 & 305 & 117 & 6.63 & 0.268 & 0.34 \\
\hline 13 & 320 & 22.4 & 1.21 & 0.082 & 21.0 \\
\hline 14 & 330 & 68.5 & 3.12 & 0.131 & 1.18 \\
\hline 15 & 330 & 137 & 7.67 & 0.324 & 0.144 \\
\hline 16 & 305 & 39 & 2.01 & 0.10 & 2.1 \\
\hline 17 & 335 & 245 & 11.2 & 0.639 & 0.12 \\
\hline 18 & 300 & & & 0.28 & 0.16 \\
\hline \multicolumn{6}{|c|}{ 2) Crude $\gamma$-globulin fraction(2) } \\
\hline 1 & 280 & 512 & 31.2 & 1.29 & 0.932 \\
\hline 2 & 280 & 259 & 14.8 & 0.653 & 0.792 \\
\hline 3 & 265 & 135 & 7.85 & 0.569 & 2.33 \\
\hline 4 & 260 & 418 & 21.85 & 0.786 & 0.629 \\
\hline 5 & 275 & 1015 & 58.9 & 2.33 & 1.12 \\
\hline 6 & 265 & 187 & 9.46 & 0.496 & 1.86 \\
\hline 7 & 255 & 113 & 2.86 & 0.250 & 4.66 \\
\hline 8 & 255 & 340 & 17.31 & 0.731 & 1.35 \\
\hline 9 & 260 & 555 & 16.8 & 1.41 & 0.653 \\
\hline 10 & 270 & 802 & 25.5 & 1.29 & 0.653 \\
\hline 11 & 255 & 141 & 9.03 & 0.405 & 2.80 \\
\hline 12 & 275 & 209 & 11.7 & 0.520 & 1.16 \\
\hline 13 & 270 & 428 & 21.6 & 0.839 & 0.839 \\
\hline 14 & 280 & 103 & 5.95 & 0.173 & 14.0 \\
\hline 15 & 290 & 1240 & 64.4 & 2.39 & 0.839 \\
\hline 16 & 300 & 72 & 4.06 & 0.173 & 9.32 \\
\hline 17 & 270 & 159 & 10.2 & 0.302 & 3.72 \\
\hline 18 & 300 & 384 & 22.6 & 0.702 & 1.31 \\
\hline 19 & 290 & 39.8 & 2.21 & 0.09 & 107 \\
\hline 20 & 295 & 48.9 & 2.92 & 0.152 & 43.8 \\
\hline 21 & 295 & 72.3 & 4.62 & 0.212 & 28.0 \\
\hline 22 & 305 & 47.3 & 2.98 & 0.139 & 32.6 \\
\hline 23 & 315 & 68.7 & 4.36 & 0.155 & 14.9 \\
\hline 24 & 305 & 45.7 & 3.22 & 0.109 & 83.9 \\
\hline 25 & 315 & 36.6 & 1.70 & 0.100 & 192 \\
\hline
\end{tabular}

* Antigen concentration in a Dale bath required to cause an anaphylactic reaction equivalent to the one caused by acetylcholine in the concentration of $10^{-8} \mathrm{~g} / \mathrm{cc}$. 
to be the case also in the present experiment. Then equation (1) was assumed and three constants in the equation were determined by the least square.

$$
(\log \mathrm{X}+\mathrm{a})(\log \mathrm{Y}+\mathrm{b})=\mathrm{c}
$$

From the calculation, equations (2) and (3) were obtained for antibodies (1) and (2), respectively.

$$
\begin{aligned}
& (\log \mathrm{X}+1.21)(\log \mathrm{Y}+1.69)=0.475 \\
& (\log \mathrm{X}+1.15)(\log \mathrm{Y}+0.46)=0.544
\end{aligned}
$$

Namely, these equations are the most reliable relations between the concentration of tissue antibody $(\mathrm{X})$ and the concentration of antigen required to cause an anaphylactic reaction of stipulated intensity $(Y)$, provided that the relation between them is hyperbolic. In other words, the inhibition of anaphylactic reaction due to antigen excess was never observed in these experiments. In fact, in any case of the sensitization made with a large amount of antibody or that with a small amount, the more the concentration of

\begin{tabular}{|c|c|c|c|c|c|}
\hline $\begin{array}{l}\text { Body } \\
\text { weight }\end{array}$ & $\begin{array}{l}\text { Antihody } \\
\text { injected }\end{array}$ & $\begin{array}{l}\text { Circulating } \\
\text { antibody }\end{array}$ & $\begin{array}{l}\text { Tissue } \\
\text { antibody }\end{array}$ & $\begin{array}{l}\text { Antigen } \\
\text { added }\end{array}$ & $\begin{array}{l}\text { Intensity of } \\
\text { contraction }\end{array}$ \\
\hline \multirow[t]{3}{*}{$\mathrm{g}$} & $\mu \mathrm{gN} / 100 \mathrm{~g}$ & $\mu \mathrm{g} N / \mathrm{cc}$ & $\mu \mathrm{gN} / \mathrm{g}$ & $\mu \mathrm{g} \cdot \mathrm{N} / \mathrm{cc}$ & $\times 10^{-8} \mathrm{~g} / \mathrm{cc}$ \\
\hline & & & & 23.2 & - \\
\hline & & & & 46.6 & 0.3 \\
\hline \multirow[t]{5}{*}{290} & 39.8 & 2.21 & 0.09 & 93.0 & 0.9 \\
\hline & antibody & & & 107 & 1.0 \\
\hline & & & & 140 & 1.3 \\
\hline & & & & 0.56 & 一 \\
\hline & & & & 1.69 & 0.3 \\
\hline \multirow[t]{3}{*}{290} & 53.1 & 2.95 & 0.109 & 2.55 & 0.8 \\
\hline & antibody & & & 2.36 & 1.0 \\
\hline & (2) & & & 2.86 & 1.2 \\
\hline
\end{tabular}

Table 2. Relation between the antigen concentration and the intensity of contraction

antigen used, so much stronger the reaction produced. The findings shown in Table 2 are the extreme cases in which the concentration of tissue antibody is near the threshold value. From this table, it is clear that the inhibition is never observed even when 10000 times to 30000 times as much as the equivalent concentration of antigen was added into the bath.

On the other hand, the apices of these hyperbola were not in accordance with the equivalent point of precipitin reaction. Namely, in case of antibody (1), the ratio of antibody/antigen on the apex was about 4 times antigen excess as compared with the equivalent point. Moreover, in case of antibody (2), the ratio of antigen to antibody on the apex was about 30 times as much as the equivalent ratio. These findings are quite different from the one observed in diphtheria toxin-guinea pig antitoxin system (Ishizaka et al.., 1956). 
2. Comparison between the Pattern of Anaphylactic Reaction and That of Precipitin or Complement Fixation Reaction.

As described above, the pattern of anaphylactic contraction of intestine is different depending on the antibody used for the experiment.

In this connection, comparisons were made between the two antibody solutions by precipitation and complement fixation reaction.

It has been assumed that the anaphylactic reaction is caused by antigen antibody reaction on the surface of the tissues or cells, while, in case of ring test, antigen and antibody react at the interface. Moreover, it is said that inhibition does not occur so readily in ring test since the reactants diffuse into one another on standing. Thus, comparisons were made between the:

Table 3. Results of ring test

\begin{tabular}{|c|c|c|c|c|c|c|c|c|c|c|c|}
\hline \multirow{2}{*}{$\begin{array}{l}\text { Dilution of } \\
\text { antibody }\end{array}$} & \multicolumn{11}{|c|}{ Dilution of antigen $2^{n}$} \\
\hline & 0 & 1 & 2 & 3 & 4 & 5 & 6 & 7 & 8 & 9 & 10 \\
\hline \multicolumn{12}{|c|}{ 1) Globulin fraction of antiserum (I): $1.027 \mathrm{mgN}$ antibody/ce $B$} \\
\hline $10 \times$ & 10 & 10 & 10 & 10 & 10 & 10 & 10 & 10 & 25 & \pm & \pm \\
\hline $20 \times$ & 10 & 10 & 10 & 10 & 10 & 10 & 10 & 10 & 25 & \pm & \pm \\
\hline $40 \times$ & 10 & 10 & 10 & 10 & 10 & 10 & 10 & 10 & 25 & \pm & \pm \\
\hline $80 \times$ & \pm & 30 & 30 & 30 & 10 & 10 & 10 & 10 & 15 & 35 & \pm \\
\hline $160 \times$ & - & - & - & - & - & \pm & \pm & \pm & \pm & \pm & \pm \\
\hline
\end{tabular}

2) Globulin fraction of antiserum (II) : $1.442 \mathrm{mgN}$ antibody/ce BSA: $0.233 \mathrm{mgN} / \mathrm{cc}$

\begin{tabular}{rccccccccccc}
\hline $10 \times$ & 10 & 10 & 10 & 10 & 10 & 10 & 10 & 10 & 15 & 20 & 20 \\
$20 \times$ & 10 & 10 & 10 & 10 & 10 & 10 & 10 & 10 & 15 & 20 & 20 \\
$40 \times$ & 10 & 10 & 10 & 10 & 10 & 10 & 10 & 20 & 20 & 30 & - \\
$80 \times$ & \pm & 20 & 20 & 10 & 10 & 10 & 15 & 30 & 30 & - & - \\
$160 \times$ & - & - & - & - & - & - & - & - & - & - & - \\
\hline
\end{tabular}

Numerals represent time in minutes required for the appearance of reaction

pattern of anaphylactic reaction and that of ring test. Table 3 shows the pattern of ring test. Namely, inhibition due to antigen excess was observed when the concentration of antigen was 32 to 128 times as much as the equivalent. Patterns of ring test using two sera, which are different from each other in anaphylactic reaction, were almost similar.

In the next test, complement fixation reaction was carried out. The patterns obtained are shown in Table 4. Then, quantitative complement fixation test was carried out. The relation of antibody to antigen in the mixtures was the optimal proportion. As the result of this, units of complement combined with antibody solutions (1) and (2) with the addition of optimal amount of antigen were $19150 \mathrm{CH}_{50}$ and $19084 \mathrm{CH}_{50}$ per antibody-mgN, respectively. In other words, the complement fixability of these antibody solution (1 and 2). 
was almost similar, though the pattern of anaphylactic reaction was different from each other.

Comparison among the two-dimentional patterns of anaphylactic reaction, ring test and complement fixation test were shown in Fig. 3. From this figure, it is clear that the threshold concentrations of antibody required for the appearance of each reaction are $10 \mu \mathrm{gN} / \mathrm{cc}$ in ring test, about $1 \mu \mathrm{gN} / \mathrm{cc}$ in complement fixation test and $0.1 \mu \mathrm{gN} / \mathrm{g}$ of tissue in anaphylactic reaction. However, for the detection of antigen, complement fixation reaction was more sensitive than anaphylactic contraction of the intestine.

Table 4. Results of complement fixation test

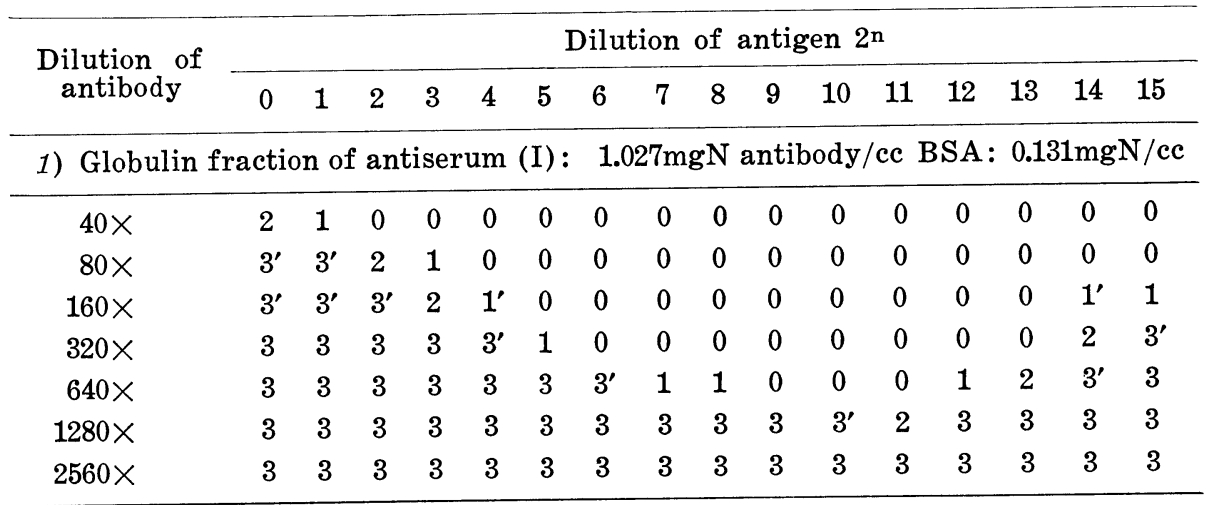

Dosis of complement fixed: $19,157 \mathrm{CH}_{50} / \mathrm{mgN}$ antibody

2) Globulin fraction of antiserum (II) : $1.442 \mathrm{mgN}$ antibody/cc BSA: $0.233 \mathrm{mgN} / \mathrm{cc}$

\begin{tabular}{rllllllllllllll}
\hline $80 \times$ & 0 & 0 & 0 & 0 & 0 & 0 & 0 & 0 & 0 & 0 & 0 & 0 & 0 & \\
$160 \times$ & 0 & 0 & 0 & 0 & 0 & 0 & 0 & 0 & 0 & 0 & 0 & $1^{\prime}$ & 2 & \\
$320 \times$ & 0 & 0 & 0 & 0 & 0 & 0 & 0 & 0 & 0 & 0 & $1^{\prime}$ & 2 & 3 & \\
$640 \times$ & 1 & 0 & 0 & 0 & 0 & 0 & 0 & 0 & 0 & 0 & $2^{\prime}$ & $3^{\prime}$ & 3 & \\
$1280 \times$ & 3 & $3^{\prime}$ & 2 & 0 & 0 & 0 & 0 & 0 & $1^{\prime}$ & $3^{\prime}$ & 3 & 3 & 3 \\
$2560 \times$ & 3 & 3 & 3 & 3 & 3 & 3 & 3 & 3 & 3 & 3 & 3 & 3 & 3
\end{tabular}

Dosis of complement fixed: $19,084 \mathrm{CH}_{50} / \mathrm{mgN}$ antibody

The inhibition of the reactions due to antigen excess was observed in ring test as well as in complement fixation test when the concentration of antigen was so high as $0.1 \mathrm{mgN} / \mathrm{cc}$. On the contrary, it was never observed in anaphylactic contraction even when the same concentration of antigen was used. This finding implies that the lack of zone phenomenon in anaphylactic reaction is not explained by the diffusion of antigen which would be the case in ring test.

3. Comparison between the Sensitizing Activity of $\beta+\gamma_{1}$-Globulin Fraction of Antiserum and That of $\gamma_{2}$-Globulin Fraction.

Kuhns $(1954 ; 1955)$ reported that the skin-sensitizing antibody of human diphtheria antitoxin was $\gamma_{1}$-globulin and that the antitoxin in $\gamma_{2}$-globulin 


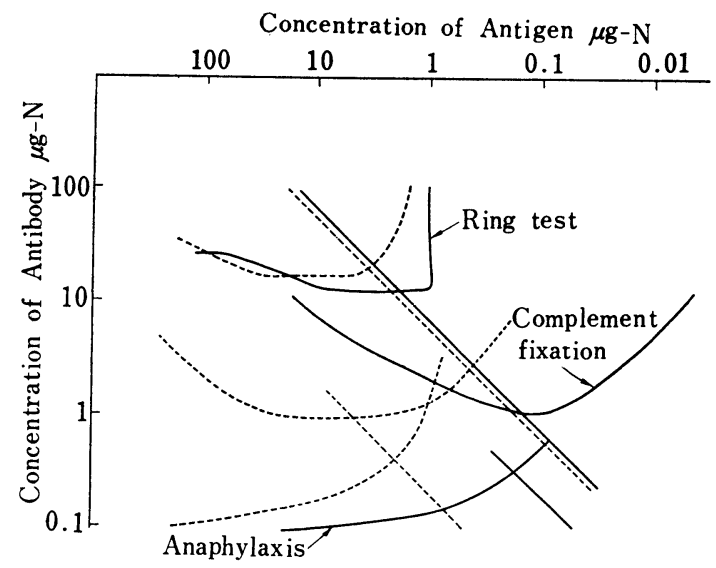

Fig. 3. Comparison of precipitation, complement fixation and anaphylaxis in vitro.

crude $\gamma$-globulin (1)

-.- crude $\gamma$-globulin (2)

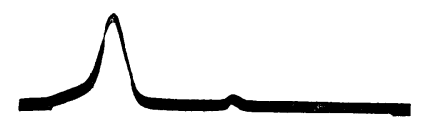

$\rightarrow \gamma_{2}$ globulin.

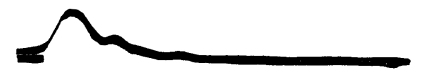

$\rightarrow \beta+\gamma_{1}$ globulin.

Fig. 4. Electrophoresis of $\gamma_{2}$-and $\beta+\gamma_{1}$-globulin fractions.

Table 5. Composition of $\beta+\gamma_{1}$ and $\gamma_{2}$-globulin fraction of antiserum

\begin{tabular}{cccccc}
\hline Praction & Plbumin & $\alpha$-globulin & $\beta$-globulin & $\gamma_{1}$-globulin & $\gamma_{2}$-globulin \\
\hline & $\%$ & $\%$ & $\%$ & $\%$ & $\%$ \\
$\beta+\gamma_{1}$ & 6.8 & 0 & 24.4 & 68.8 & 0 \\
$\gamma_{2}$ & 5.6 & 0 & 0 & 0 & 94.4 \\
\hline
\end{tabular}

fraction did not have the sensitizing activity. But, in case of hay fever, it was reported that the skin-sensitizing antibody was not $\gamma_{2}$-globulin (Campbell et al., 1954; Cooke, Sherman and Menzel, 1951). In this connection, $\gamma_{2}$-globulin fraction and $\beta+\gamma_{1}$-globulin fraction were obtained from anti-BSA rabbit serum and their sensitizing activities were compared with each other in anaphylactic contraction of intestine. Namely, both fractions were analyzed by electrophoresis and their composition was determined. The patterns obtained in a $\mathrm{pH} 8.6$ veronal buffer containing $0.1 \mathrm{M}$ sodium diethylbarbiturate and $0.02 \mathrm{M}$ dietylbarbituric acid were shown in Fig. 4, and the composition of each fraction is shown in Table 5 .

Both fractions were labeled with $\mathrm{I}^{131}$ and their antibody content was determined by quantitative precipitin reaction. Guinea pigs were sensitized 
Table 6. Comparison between the sensitizing activity of $\beta+\gamma_{1}-$ globulin fraction and that of $\gamma_{2}$-globulin fraction

\begin{tabular}{|c|c|c|c|c|c|c|}
\hline No & $\begin{array}{l}\text { Body } \\
\text { weight }\end{array}$ & $\begin{array}{l}\text { Antibody } \\
\text { injected }\end{array}$ & $\begin{array}{l}\text { Circulating } \\
\text { antibody }\end{array}$ & $\begin{array}{c}\text { Tissue } \\
\text { antibody }\end{array}$ & $\begin{array}{c}\text { Antigen } \\
\text { concentration* }\end{array}$ & $\frac{\text { Tissue-A }}{\text { Circulating-A }}$ \\
\hline \multicolumn{7}{|c|}{ n fra } \\
\hline & $\mathrm{g}$ & $\mu \mathrm{gN} / 100$ & $\mu \mathrm{gN} / \mathrm{cc}$ & $\mu \mathrm{gN} / \mathrm{g}$ & $\mu \mathrm{gN} / \mathrm{cc}$ & $\%$ \\
\hline 1 & 305 & 287 & 22.8 & 1.03 & 0.362 & 4.53 \\
\hline 2 & 280 & 78.2 & 7.21 & 0.22 & 0.50 & 3.05 \\
\hline 3 & 315 & 138 & 16.5 & 1.01 & 0.348 & 6.13 \\
\hline 4 & 330 & 26.5 & 3.6 & 0.124 & 2.78 & 3.44 \\
\hline 5 & 300 & 219 & 18.0 & 0.862 & 0.417 & 4.79 \\
\hline 6 & 350 & 50.0 & 4.93 & 0.251 & 0.556 & 5.08 \\
\hline 7 & 325 & 67.3 & 3.4 & 0.141 & 1.945 & 4.15 \\
\hline 8 & 320 & 21.8 & 1.8 & 0.104 & 6.26 & 5.75 \\
\hline 9 & 355 & 74.0 & 6.3 & 0.311 & 0.50 & 4.94 \\
\hline 10 & 300 & 21.9 & 2.03 & 0.083 & 31.2 & 4.09 \\
\hline 11 & 275 & 47.7 & 2.9 & 0.174 & 1.03 & 6.00 \\
\hline 12 & 275 & 127 & 8.78 & 0.625 & 0.44 & 7.11 \\
\hline 13 & 300 & 17.5 & 1.78 & 0.087 & 11.1 & 4.89 \\
\hline 14 & 315 & 416 & 36.5 & 1.47 & 0.272 & 4.02 \\
\hline 15 & 320 & 15.0 & 1.78 & 0.083 & 41.7 & 4.66 \\
\hline
\end{tabular}

2) $\gamma_{2}$-globulin fraction

\begin{tabular}{rcccccc}
\hline & $\mathrm{g}$ & $\mu \mathrm{gN} / 100$ & $\mu \mathrm{gN} / \mathrm{cc}$ & $\mu \mathrm{gN} / \mathrm{g}$ & $\mu \mathrm{gN} / \mathrm{cc}$ & $\%$ \\
1 & 310 & 166 & 20.2 & 0.755 & 0.306 & 3.7 \\
2 & 255 & 194 & 22.2 & 0.965 & 0.278 & 4.35 \\
3 & 280 & 55.2 & 6.8 & $0.20<$ & 0.495 & 2.96 \\
4 & 340 & 32.5 & 5.2 & 0.136 & 4.44 & 2.62 \\
5 & 345 & 44.7 & 5.07 & 0.152 & 1.11 & 3.00 \\
6 & 325 & 79.2 & 15.6 & 0.438 & 0.50 & 2.81 \\
7 & 325 & 25.3 & 3.18 & 0.103 & 2.78 & 3.24 \\
8 & 300 & 30.8 & 4.58 & 0.148 & 0.92 & 3.24 \\
9 & 300 & 515 & 63.8 & 2.60 & 0.195 & 4.08 \\
10 & 285 & 18.1 & 2.60 & 0.124 & 2.50 & 4.77 \\
11 & 315 & 19.2 & 2.18 & 0.128 & 1.03 & 5.87 \\
12 & 295 & 27.9 & 3.50 & 0.177 & 1.56 & 5.06 \\
13 & 305 & 13.5 & 1.85 & 0.091 & 10.6 & 4.92 \\
14 & 310 & 15.0 & 2.18 & 0.103 & 3.34 & 4.71 \\
15 & 300 & 12.0 & 2.18 & 0.078 & 22.2 & 3.58 \\
\hline
\end{tabular}

* Antigen concentration in a Dale bath required to cause an anaphylactic reaction equivalent to the one caused by acetylcholine in the concentration of $10-^{8} \mathrm{~g} / \mathrm{cc}$. 
with each fraction and the concentration of BSA required to cause an anaphylactic contraction of standard strength was determined in each animal. The concentration of tissue antibody was determined from the radioactivity. The results are shown in Table 6 and the relations between the concentration of tissue antibody and the concentration of antigen required were illustrated in Fig. 5. From this finding, The equations obtained by $\beta+\gamma_{1}$-globulin fraction and $\gamma_{2}$-globulin fraction are as follows:

$$
\begin{aligned}
& (\log X+1.43)(\log Y+1.20)=0.944 \\
& (\log X+1.18)(\log Y+0.80)=0.293
\end{aligned}
$$

From this finding, it may safely be said that the relation is just similar being independent, of the difference of the fraction used. Moreover, the threshold

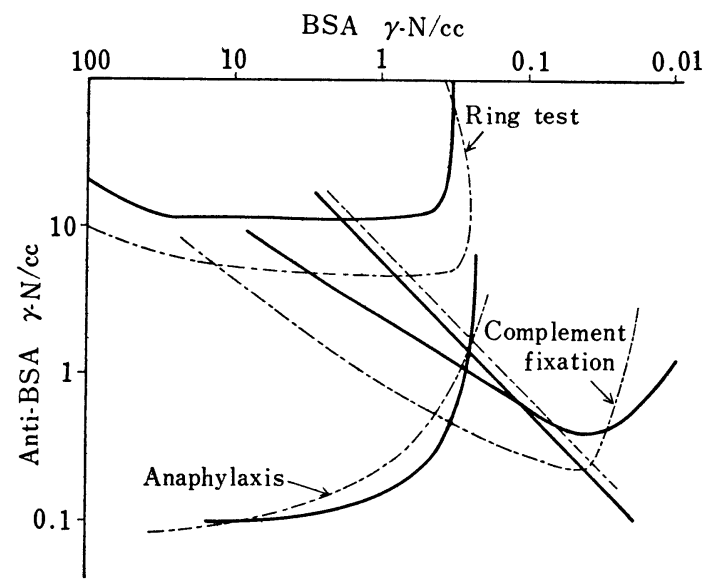

Fig. 5. Comparison of $\gamma_{2}$-globulin fraction to $\beta$-globulin fraction of antiserum in precipitation, complement fixation and anaphylaxis in vitro.

$$
\gamma_{2}
$$

concentration of tissue antibody was about $0.1 \mu \mathrm{gN} / \mathrm{g}$ of tissue in both cases. However, the ratio between the tissue antibody concentration and the circulating antibody concentration 24 hours after the sensitization was different. depending on the property of antibody. Namely, the ratio was 2.6 to $5 \%$ in $\gamma_{2}$-globulin fraction, however, it was 3 to $6 \%$ in $\beta+\gamma_{1}$-globulin fraction. In this sense, it seems that the sensitizing activity of $\beta+\gamma_{1}$-globulin fraction is a little stronger than that of $\gamma_{2}$-globulin fraction, provided that the same dosage of antibody is used for sensitization.

Patterns of ring test as well as complement fixation test were determined in both fractions (Fig. 5). Considered in relation to antibody nitrogen, complement fixability of antibody was also determined by quantitative complement. fixation reaction. Therefore, $\gamma_{2}$-globulin fraction fixed less complement $(73400$ 
$\mathrm{CH}_{50} /$ antibody $\mathrm{mgN}$ ) than did $\beta+\gamma_{1}$-globulin fraction $\left(87300 \mathrm{CH}_{50} /\right.$ antibody $\mathrm{mgN}$ ).

\section{Discussion}

As reported previously, quantitative relationship between the concentration of tissue antibody and the concentration of antigen required to cause an anaphylactic contraction in a certain intensity is hyperbolic. In other words, inhibition of the reaction in the region of antigen excess has never been observed in the anaphylactic contraction of the intestine. In the previous report, however, the concentration of antigen was less than 430 times as much as the equivalent concentration to tissue antibody. In order to confirm the lack of the inhibition in the extremely antigen excess region, the quantitative studies were repeated again using BSA-antiBSA system with the corresponding results. Namely, the inhibition of the anaphylactic reaction was never observed even when the antigen concentration was more than 10000 times as much as the equivalent concentration of tissue antibody.

In the previous report (Ishizaka et al., 1956), the apex of hyperbola representing the quantitative relation was near the equivalent point. But it was in the region of antigen excess when the anti-BSA rabbit antibody was used for passive sensitization. Moreover, the apices of two hyperbola obtained with two antisera were different from each other. The reason for such discrepancy is not clear, although the presence of the nonsensitizing antibody in the rabbit antiserum can be postulated. Because, the apex of hyperbola was in the region of antigen excess when the nonsensitizing antibody coexisted with the sensitizing antibody (Ishizaka et al., 1957). At any rate, it might be possible that the proportion of antigen to antibody corresponding the apex of hyperbola would be a kind of optimal proportion in anaphylactic contraction of intestine. Accordingly, the extreme antigen excess region, in which the inhibition was not observed, was 1000 to 2500 times as much as the optimal proportion.

On the other hand, inhibition of complement fixation was observed when the antigen concentration was 8 to 32 times in excess. In case of the ring test, it is said that the inhibition does not occur so readily since the reactants diffuse into one another on standing. Even in the test, however, the inhibition was observed when the concentration of antigen was 32 to 128 times as much as the equivalent concentration. Therefore, the lack of the inhibition in the anaphylactic contraction can not be explained by the diffusion of antigen into the tissues and it is likely that the inhibition due to antigen excess never occurs in anaphylactic contraction of intestine.

According to Kabat and Mayer (1948), the contraction of uterine horn occurred in some instances even when 0.02 and $0.01 \mathrm{mg}$ antibody- $\mathrm{N}$ was used in passive sensitization. If the antibody injected is assumed to be uniformely distributed throughout the body of animal, the amount present in the contract- 
ing uterine strip $(75 \mathrm{mg}$ ) would be of the order of $0.01 \mu \mathrm{gN}$. As the result of the present experiment, however, the antibody injected did not distribute uniformly throughout the body within 24 hours after the passive sensitization but the concentration of antibody in the intestine was about 3 to $5 \%$ of its concentration in the serum. The minimum concentration of antibody in the intestine required to cause an anaphylactic contraction in the standard strength corresponding to the one caused by acetylcholine in the concentration of $10^{-8} \mathrm{~g} / \mathrm{cc}$ ) was less than $0.1 \mu \mathrm{gN} / \mathrm{g}$. This value is almost similar to the one estimated by Kabat and Mayer (1948). As reported in the previous report, the threshold concentration of tissue antibody required to cause a weak anaphylactic reaction is generally smaller that the one required to cause the stronger reaction (Ishizaka et al., 1956). Therefore, it may safely be said that the minimum concentration of tissue antibody required to cause a detectable contraction is smaller than $0.1 \mu \mathrm{gN} / \mathrm{g}$. On the other hand, the threshold concentrations of the same antibody required to cause precipitation and complement fixation reaction were about $10 \mu \mathrm{gN} / \mathrm{cc}$ and 0.3 to $1 \mu \mathrm{gN} / \mathrm{cc}$, respectively. From this finding, it was confirmed that the minimal concentration of antibody $\mathrm{N}$ necessary to sensitize smooth muscle tissue was less than can be detected by any in vitro immunological method such as precipitation and complement fixation.

The relation of the sensitizing activity and the chemical property of antibody is not yet properly understood and has been the subject of much discussion. For example, Cook and associates (1951) subjected allergic sera to electrophoresis and concluded that the bulk of sensitizing antibody was not associated with gamma globulin. Vaughan Favour and Jaffee (1952) studied the skinsensitizing antibody in ragweed hay fever patients, using Cohn's alcohol precipitation method. The skin sensitizing antibody was shown to be concentrated in the proteins of Fraction IIId, which was believed to consist primarily of $\beta$-globulin. In this connection, comparisons were made between the sensitizing activity of $\gamma_{2}$-globulin fraction and that of $\beta+\gamma_{1}$-globulin fraction in anaphylactic contraction of intestine. The electrophoretic analysis indicated that $\beta+\gamma_{1}$-globulin fraction consisted primarily of $\gamma_{1}$-globulin $(68.8 \%)$ and $\beta$-globulin $(24.4 \%)$, while $94.4 \%$ of $\gamma_{2}$-globulin fraction was $\gamma_{2}$-globulin. Using these fractions, however, similar relations between the tissue antibody and the antigen required, were obtained (Fig. 5). Therefore, it can be said that the property of antibody-whether the antibody is $\gamma_{2}$-globulin or $\gamma_{1}$-globulin-has nothing to do with their sensitizing activity, so far as the anaphylactic contraction of guinea pig intestine is concerned. On the other hand, complement fixability of antibody was different depending on the property of antibody. Namely, $\gamma_{1}$-globulin-antibody fixed more complement than did the $\gamma_{2}$-globulin-antibody. These findings are in accordance with the one reported by Rice (1946), who observed that the anti-SIII in euglobulin fraction of rabbit antiserum combined more complement than did the antibody in 
psudoglobulin fraction. In diphtheria toxin antitoxin system, equine antitoxin possesses neither complement fixability nor sensitizing activity. while rabbit antitoxin as well as guinea pig antitoxin has both activities (Ishizaka et al., 1957a). This finding implies a close relation between complement fixability and sensitizing activity of antibody. Quantitatively, however, these activities would not necessarily parallel with each other.

\section{SUMMARY}

1. Anaphylactic contraction of guinea pig intestine was studied quantitatively in BSA-antiBSA system and the quantitative relation was compared with the pattern of precipitation and complement fixation.

2. The relation between the concentration of tissue antibody and that of antigen required to cause an anaphylactic contraction in a certain intensity was hyperbolic. But, the patterns of the both serological reactions in vitro were parabolic. In other words, the lack of the inhibition due to antigen excess would be one of the characteristic properties in anaphylactic reaction.

3. The apex of hyperbola representing the quantitative relation in anaphylactic reaction was in the region of antigen excess.

4. The threshold concentration of tissue antibody necessary to cause an anaphylactic contraction was about $0.1 \mu \mathrm{gN}$ or less per $\mathrm{g}$ of tissue, whereas the minimum concentrations of the antibody which could be detected by ring test and complement fixation test were $10 \mu \mathrm{N}$ and 0.3 to $1 \mu \mathrm{gN} / \mathrm{cc}$, respectively.

5. Significant difference was not observed between the sensitizing activity of $\gamma_{2}$-globulin antibody and that of $\gamma_{1}$-globulin antibody, though their complement fixability were different from each other.

The authors wish to express their gratitude for cordial guidance of Dr. K. Nakamura and assistance of Dr. Y. Ichikawa of the National Institute of Health, Tokyo.

\section{REFERENCES}

Campbell, D. H., Cann, J. R., Freidman, T. B. and Brown, R. A. (1954): The relation of allergy reagins to electrophoretic components of serum. Science, 119, 289-291.

Cooke, R. A., Sherman, W. B., Menzel, A. E. O., Chapin, H. B., Howell, C. M., Scott, R. B., Myers, P. A. and Downing, L. H. (1951): ACTH and Cortisone in allergic diseases. J. Allergy, 22, 211-236.

Heidelberger, M. and Kendall, F. E. (1935): A quantitative theory of the precipitin reaction. III. The relat reaction between crystalline egg albumin and its homologous antibody. J. Exper. Med., 62, 697-720.

Ishizaka, K., Ishizaka, T. and Sugahara, T. (1956): Quantitative studies on anaphylaxis in vitro I. Proportion of antigen concentration to tissue antibody concentration in toxin anaphylaxis of diphtheria. Jap. J. M. Sc. \& Biol., 9, 191-204.

Ishizaka, K., Ishizaka, T. and Sugahara, T. (1957): Quantitative studies on anaphylaxis in vitro. II. Studies on the species difference of diphtheria antitoxin in sensitizing activity. Jap. J. M. Sc. \& Biol., 10, 93-103. 
Ishizaka, K., Ishizaka, T., Sugahara, T. and Maruyama, S. (1957 a) : Studies on the relationship between toxin-anaphylaxis and antitoxic immunity. III. Significance of tissue antitoxin on Schick-reaction. Jap. J. M. Sc. \& Biol., 10, 343-361.

Kabat, E. A. and Mayer, M. M. (1948): Experimental Immunochemistry, Charles C. Thomas, pp. 143-151.

Kuhns, W. J. (1954): Immunochemical studies of antitoxin produced in normal and allergic individuals hyperimmunized with diphtheria toxoid. IV. Differences between human diphtheria antitoxin as shown by electrophoresis. J. Exper. Med., 99, $577-588$.

Kuhns, W. J. (1955) : Immunological properties of a form of nonprecipitating diphtheria antitoxin which does not sensitize human skin. Studies of its relation to the inhibiting reaction. J. Immunol., 75, 105-111.

Mayer, M. M., Osler, A. G., Bier, O. and Heidelberger, M. (1948) : Quantitative studies of complement fixation. I. Method. J. Immunol., 59, 185-206.

Nichol, C and Deutsch, H. F. (1948): Biophysical studies of blood plasma proteins. VII. Separation of $\gamma$-globulin from the sera of various animals. J. Am. Chem. Soc., 70, 80-83.

Rice, C. E. and Sickles, G. R. (1946): Studies of antipneumococcal serum. VII. Complement fixing activity of fractionated rabbit serum. J. Immunol., 54, 267-274.

Stein, G. J. and Ngu, D. V. (1950): A quantitative complement fixation test: Titration of luetic sera by the unit of 50 per cent hemolysis. J. Immunol., 65, 17-37.

Vaughan, J. H., Favour, C. B. and Jaffee, I. H. (1952) : Partition of the skinsensitizing antibody among alcohol-fractionated plasma proteins. J. Allergy, 23, 489-492. 